\title{
Pattern of Keratinization in Oral Squamous Cells during Carcinogenesis
}

\author{
Dr Abhimanyu Mohanta, Ph.D ${ }^{1}$; Dr Prafulla K. Mohanty, Ph.D ${ }^{2}$; \\ Dr Gadadhar Parida, M.D. ${ }^{3}$ \\ ${ }^{1 .}$ UGC Research Fellow, P.G. Department of Zoology, Utkal University, Vani Vihar, Bhubaneshwar, Odisha, \\ India-751 004. \\ ${ }^{2}$ Professor and Head, P.G. Department of Zoology, Utkal University, Vani Vihar, Bhubaneshwar, Odisha, \\ India-751 004. \\ ${ }^{3 .}$ Former Professor and Head, Department of Oncopathology, Acharya Harihar Regional Cancer Center \\ (AHRCC), Cuttack, Odisha, India-753 007.
}

\begin{abstract}
:
Background: Oral carcinogenesis is a multi-step process. Broadly, oral squamous cell carcinoma (OSCC) can be well-, moderately- or poorly-differentiated, and either keratinizing or non-keratinizing. Most cases are moderately to poorly-differentiated. Precursor lesions (dysplasia) can be categorized into mild, moderate, or severe (carcinoma in situ).In the present study, the pattern of keratin expression in oral squamous cells during carcinogenesis is vividly analysed.

Materials and Methods: Samples in the form of scraped and exfoliated cytosmear were collected from the affected sites of the clinically diagnosed 136 oral cancer patients and were immediately fixed in acetoalcohol (1:3). The wet fixed smears were stained by routine Papanicolaou's staining protocol and Giemsa's solution. Stained tissues were studied under the microscope.

Results: Cytological pleomorphism is a unique feature observed during carcinogenesis. There appears to be a spectrum of degrees of keratinization rather than distinct types, and the degree of keratinization is reflected in the degree of packing and orientation of keratin filaments. It is presumed that alteration in the architectural regularity of the cell membrane is an important aspect of keratinization which leads to cytological pleomorphism during oral carcinogenesis.

Conclusion: Pattern of keratinization alongwith cytological pleomorphism in exfoliated epithelial squamous cells has a practical utility in the diagnosis and early detection of oral cancer during carcinogenesis.
\end{abstract}

Keywords: Carcinogenesis, Keratinization, Keratins, Oral squamous cell carcinoma.

\section{Introduction}

Keratins are defined as intermediate filament forming proteins with specific physicochemical properties produced in any vertebrate epithelia [1]. These are primarily responsible for maintaining the structural integrity of keratinocytes [2]. These belong to multigene family of proteins constituting $85 \%$ of the total cellular protein in the cornified cells of the epidermis [3, 4]. In humans, there are around 30 keratin families divided into two groups, namely, acidic and basic keratins, which are arranged in pairs. They are expressed in a highly specific pattern related to the epithelial type and stage of cellular differentiation. The different types of keratin and their associated proteins serve as important markers of differentiation thus aiding in diagnosis of various pathological conditions including cancer [5-7]. The keratin proteins have a uniform mode of distribution among the various layers of epithelium which gives an indication of the disease process. Also, various disorders are associated with defects in the keratin and their associated proteins which may manifest in skin or oral cavity or both [8]. The keratins and keratin-associated proteins are useful as differentiation markers because their expression is both region specific and differentiation specific. Antibodies to keratin are considered as important tissue differentiation markers and therefore are an integral aid in diagnostic pathology It has been reported that $\mathrm{K} 8$ is associated with transformation and increased malignant potential of oral squamous epithelial cells $[9,10]$. In the present study, the pattern of keratin expression in the pleomorphic oral squamous cells during carcinogenesis is analysed.

\section{Materials And Methods}

Samples in the form of scraped and exfoliated cytosmear were collected during May 2007 to May 2009 from the affected sites of the clinically diagnosed 136 oral cancer patients, who have registered at the Outpatient Department (OPD) of Acharya Harihar Regional Cancer Centre, Cuttack, Odisha- the only Government Hospital for the treatment of cancer patient. Two smearing slides were prepared from each affected site. The 
collected tissues in the form of smears on the slides were immediately fixed in acetoalcohol (1:3). Prior to the collection, the case history of the patients were collected through prepared questionnaire form. The wet fixed smears were stained by routine Papanicolaou's staining protocol and Giemsa's solution. Photomicrographs of the tissues were taken out as supporting evidence. The findings were statistically analyzed, interpreted and correlated with age, sex and addiction of the patients.

\section{Ethical considerations}

This study was approved by Institutional Ethical Committee of Utkal University, Bhubaneswar and necessary permission from the Director, AHRCC, Cuttack, Odisha, India was also obtained

\section{Results}

Analysis of the samples was carried out on the basis of oral sites, degree of pathogenicity, age groups and addiction to tobacco and alcohol in both sexes. Along with the reported cases, a parallel set of control samples were also taken into account (Table1).

In the age group of 30-49 years out of 13 precancerous individuals, 08 males and 04 females were addicted to different habits where as only 01 female was non-addicted. In the 50-69 years of age group, 18 males and 14 females were addicted. In the age group of 70-89 years, all 06 males and 03 out of 04 females were addicted to different habits (Table 1). In cancerous group, 03 out of 25 males and none out of 06 females were non-addicted, in the 30-49 years of age group. In 50-69 years of age group, all 16 males and 22 females were addicted. In the age group of 70-89 years 01 out of 09 individual was non-addicted but all 03 females were addicted to different habits. In control group, 33 males and 11 females were in the age group of 30-49 years, 34 males and 36 females were between 50-69 years and 15 males and 07 females were in 70-89years of age group. In control group, all the individuals were non-addicted. The frequency of addiction also differs from individual to individual according to their habit. However, their duration of addiction ranges from 15-45 years.

Considering the site-specific cellular differentiations (Table 2), all the samples of both sexes in control group were found to be normal and WDSC. But, in cancer affected group, it was observed that 02 (4.8 per cent) males and 09 (13.4 per cent) females of WDSC, 02 ( 8.0 per cent) males and 01 ( 8.3 per cent) female of MDSC and 01 (6.7 per cent) male and 01(8.4 per cent) female of PDSC were from carcinoma of lip; 06 (14.3 per cent) males and 05 (16.6 per cent) females of WDSC, 03 (12.0 per cent) males and 02 (16.7 per cent) females come under MDSC and 02 (3.3 per cent) males and none of the females of PDSC were at the carcinoma of tongue; 08 (19.0 per cent) males and 04 (13.4 per cent) females having WDSC, 05 (20.0 per cent) males and 01 (8.3 per cent) females of MDSC, 03 ( 20 per cent) males and 01 ( 8.4 per cent) females with PDSC come under the carcinoma of alveolus and gingiva; 03 ( 7.1 per cent) males and 01 (3.3 per cent) female having WDSC, 02 (8.0 per cent) males and 02 (16.7 per cent) females of MDSC and 02 (13.3 per cent) males and 03 (25.0 per cent) females having PDSC were belong to the carcinoma of floor of the mouth; 03 (7.1 per cent) males and 01 (3.3 per cent) female having WDSC, 02 (8.0 per cent) males and 02 (16.7 per cent)) females having MDSC and 01 (6.7 per cent) male and none of the females with PDSC in carcinoma of palate, and 20 (47.7 per cent) males and 15 (50 per cent) females with WDSC, 11 (44.0 per cent) males and 04 (33.3 per cent) females and 06 (40.0 per cent) males and 07 (58.2 per cent) females having PDSC were in the carcinoma of buccal mucosa .

Referring to the normal oral squamous cell (Figs.1 and Fig.2), ten types of cytological atypias were detected from the exfoliated buccal smears of the oral cancer patients. Based on the pattern of keratinization, nature of staining and morphological peculiarities, these are named as (1) Keratinized spindle cell (KSC) (2) Keratinized tadpole cell (KTC), (3) Keratinized strap (Antischkow) cell (KSC-A), (4) Large keratinized fiber cell (LKFC), (5) Small keratinized fiber cell (SKFC), (6) Large keratinized round cell (LKRC), (7) Small keratinized round cell (SKRC), (8) Micronucleated cell (MNC), (9) Plump keratinized squamous cell (PKSC) and (10) Non-keratinized malignant squamous cell (NMSC). Except NMSCs, all other cells are keratinized and appear to be either well differentiated or moderately differentiated [11].

In addition to these diagnostic pleomorphic cells, whorled clusters of cells, wrapped round one another like the layers of an onion, may occasionally be seen in the exfoliated smears, are called epithelial pearls. The number of the cells in a cluster may vary from 8 to 40 or so. These were mostly observed in the smears of malignant cases. If the constituent nuclei cannot be firmly identified as malignant, and no other malignant cells are seen, their presence need not arouse suspicion [12].

Oral carcinogenesis is a long latency multistep process which proceeds from normal to precancerous to cancerous stage. During study, we have observed that the normal oral squamous cells are appeared to be sky-blue in colour in Papanicolaou's stain (Fig.1) and faint magenta colour in Giemsa stain (Fig.2). Although microncleated cells were found to be in increased frequency from normal to precancerous to cancerous stage, expression of keratin was observed to be more in erythroplakia than leukoplakia and carcinoma in situ. Plump keratinized squamous cells (PKSCs) are well differentiated and may be either hypo-or hyperkeratinized, but are restricted to erythroplakia and carcinoma in situ. Similarly, the Non-keratinized malignant squamous cells (NMSCs) are smaller in size, either oval or 
Table 1 Degree of pathogenicity, age group, sex and addiction-wise individuals

\begin{tabular}{|c|c|c|c|c|c|c|c|c|c|c|c|c|c|c|c|c|c|}
\hline \multirow{2}{*}{$\begin{array}{c}\mathrm{N} \\
\mathrm{O}\end{array}$} & \multirow{2}{*}{$\begin{array}{c}\text { Grou } \\
\mathrm{p}\end{array}$} & \multirow{2}{*}{$\begin{array}{c}\text { Age } \\
\text { grou } \\
\text { p } \\
\text { (in } \\
\text { year } \\
\text { s) }\end{array}$} & \multicolumn{2}{|c|}{$\begin{array}{c}\text { No of } \\
\text { samples }\end{array}$} & \multicolumn{2}{|c|}{ Chewers } & \multicolumn{2}{|c|}{ Smokers } & \multicolumn{2}{|c|}{ Alcoholics } & \multicolumn{2}{|c|}{$\begin{array}{l}\text { Chewer- } \\
\text { smokers }\end{array}$} & \multicolumn{2}{|c|}{$\begin{array}{l}\text { Chewer- } \\
\text { smoker- } \\
\text { alcoholics }\end{array}$} & \multicolumn{2}{|c|}{$\begin{array}{c}\text { Non- } \\
\text { addicted } \\
\text { cancerous }\end{array}$} & \multirow{2}{*}{$\begin{array}{c}\text { Tota } \\
1\end{array}$} \\
\hline & & & M & $\mathrm{F}$ & M & F & M & $\mathrm{F}$ & M & F & M & $\mathrm{F}$ & M & F & M & F & \\
\hline \multirow{3}{*}{1} & \multirow{3}{*}{$\begin{array}{c}\text { Contr } \\
\text { ol }\end{array}$} & $\begin{array}{c}30- \\
49\end{array}$ & $\begin{array}{c}33 \\
(40 . \\
2)\end{array}$ & $\begin{array}{c}11 \\
(20 . \\
4)\end{array}$ & Nil & Nil & Nil & Nil & Nil & Nil & Nil & Nil & Nil & Nil & $\begin{array}{c}33 \\
(40 . \\
2)\end{array}$ & $\begin{array}{c}11 \\
(20 . \\
4)\end{array}$ & $\begin{array}{r}44 \\
(32 . \\
4)\end{array}$ \\
\hline & & $\begin{array}{c}50- \\
69\end{array}$ & $\begin{array}{c}34 \\
(41 . \\
5)\end{array}$ & $\begin{array}{c}36 \\
(66 . \\
6)\end{array}$ & Nil & Nil & Nil & Nil & Nil & Nil & Nil & Nil & Nil & Nil & $\begin{array}{c}34 \\
(41 . \\
5)\end{array}$ & $\begin{array}{c}36 \\
(66 . \\
6)\end{array}$ & $\begin{array}{c}70 \\
(51 . \\
5)\end{array}$ \\
\hline & & $\begin{array}{l}70- \\
89\end{array}$ & $\begin{array}{c}15 \\
(18 . \\
3)\end{array}$ & $\begin{array}{c}07 \\
(13 . \\
0)\end{array}$ & Nil & Nil & Nil & Nil & Nil & Nil & Nil & Nil & Nil & Nil & $\begin{array}{c}15 \\
(18 . \\
3)\end{array}$ & $\begin{array}{c}07 \\
(13 . \\
0)\end{array}$ & $\begin{array}{c}22 \\
(16 . \\
1)\end{array}$ \\
\hline \multirow{3}{*}{2} & \multirow{3}{*}{$\begin{array}{c}\text { Preca } \\
\text { ncero } \\
\text { us }\end{array}$} & $\begin{array}{c}30- \\
49\end{array}$ & $\begin{array}{c}08 \\
(9.7 \\
)\end{array}$ & $\begin{array}{c}05 \\
(9.3)\end{array}$ & $\begin{array}{c}0.2 \\
(8.6 \\
)\end{array}$ & $\begin{array}{c}03 \\
(15 . \\
0)\end{array}$ & Nil & Nil & $\begin{array}{c}01 \\
(8.4)\end{array}$ & $\begin{array}{l}01 \\
5.5\end{array}$ & $\begin{array}{c}03 \\
(12 . \\
5)\end{array}$ & Nil & $\begin{array}{c}02 \\
25.0\end{array}$ & Nil & Nil & $\begin{array}{c}01 \\
25.0\end{array}$ & $\begin{array}{c}13 \\
(9.5 \\
)\end{array}$ \\
\hline & & $\begin{array}{c}50- \\
69\end{array}$ & $\begin{array}{c}18 \\
(22 . \\
0)\end{array}$ & $\begin{array}{c}14 \\
(25 . \\
9)\end{array}$ & $\begin{array}{r}03 \\
(13 . \\
0)\end{array}$ & $\begin{array}{c}07 \\
(35 . \\
0)\end{array}$ & $\begin{array}{r}03 \\
(33 . \\
04)\end{array}$ & $\begin{array}{c}01 \\
(50.0 \\
)\end{array}$ & $\begin{array}{c}02 \\
(16 . \\
6)\end{array}$ & $\begin{array}{c}04 \\
(22 . \\
3)\end{array}$ & $\begin{array}{c}09 \\
(37 . \\
5)\end{array}$ & Nil & $\begin{array}{c}01 \\
(12 . \\
5)\end{array}$ & $\begin{array}{c}02 \\
33 . \\
3\end{array}$ & Nil & Nil & $\begin{array}{c}32 \\
(23 . \\
5)\end{array}$ \\
\hline & & $\begin{array}{l}70- \\
89\end{array}$ & $\begin{array}{c}06 \\
(7.3 \\
)\end{array}$ & $\begin{array}{c}04 \\
(7.4)\end{array}$ & $\begin{array}{r}04 \\
(17 . \\
4)\end{array}$ & $\begin{array}{c}02 \\
(10 . \\
0)\end{array}$ & $\begin{array}{c}01 \\
(11 . \\
1)\end{array}$ & Nil & Nil & $\begin{array}{c}01 \\
(5.5 \\
)\end{array}$ & Nil & $\begin{array}{r}01 \\
(25 . \\
0)\end{array}$ & $\begin{array}{c}01 \\
12.5\end{array}$ & Nil & Nil & $\begin{array}{c}01 \\
(25 . \\
0)\end{array}$ & $\begin{array}{c}10 \\
(7.4 \\
)\end{array}$ \\
\hline \multirow{3}{*}{3} & \multirow{3}{*}{$\begin{array}{l}\text { Canc } \\
\text { erous }\end{array}$} & $\begin{array}{c}30- \\
49\end{array}$ & $\begin{array}{c}25 \\
(30 . \\
5)\end{array}$ & $\begin{array}{c}06 \\
(11 . \\
1)\end{array}$ & $\begin{array}{r}09 \\
(39 . \\
1)\end{array}$ & $\begin{array}{c}03 \\
(15 . \\
0)\end{array}$ & $\begin{array}{c}02 \\
(22 . \\
2)\end{array}$ & Nil & $\begin{array}{c}03 \\
(25 . \\
0)\end{array}$ & $\begin{array}{c}03 \\
(16 . \\
8)\end{array}$ & $\begin{array}{c}06 \\
(25 . \\
0)\end{array}$ & Nil & $\begin{array}{c}02 \\
(25 . \\
0)\end{array}$ & Nil & $\begin{array}{c}03 \\
(50 . \\
0)\end{array}$ & Nil & $\begin{array}{r}31 \\
(22 . \\
8)\end{array}$ \\
\hline & & $\begin{array}{c}50- \\
69\end{array}$ & $\begin{array}{c}16 \\
(19 . \\
5)\end{array}$ & $\begin{array}{c}22 \\
(40 . \\
7)\end{array}$ & $\begin{array}{r}04 \\
(17 . \\
4)\end{array}$ & $\begin{array}{c}04 \\
(20 . \\
0)\end{array}$ & $\begin{array}{c}02 \\
(22 . \\
2)\end{array}$ & $\begin{array}{c}01 \\
(50.0 \\
)\end{array}$ & $\begin{array}{c}03 \\
(25 . \\
0)\end{array}$ & $\begin{array}{c}08 \\
(44 . \\
4)\end{array}$ & $\begin{array}{c}03 \\
(12 . \\
5)\end{array}$ & $\begin{array}{r}03 \\
(75 . \\
0)\end{array}$ & $\begin{array}{c}02 \\
(25 . \\
0)\end{array}$ & $\begin{array}{c}04 \\
66 . \\
7\end{array}$ & $\begin{array}{c}02 \\
(33 . \\
3)\end{array}$ & $\begin{array}{c}02 \\
(50 . \\
0)\end{array}$ & $\begin{array}{c}38 \\
(28 . \\
0)\end{array}$ \\
\hline & & $\begin{array}{l}70- \\
89\end{array}$ & $\begin{array}{c}09 \\
(11 . \\
0)\end{array}$ & $\begin{array}{c}03 \\
(5.6)\end{array}$ & $\begin{array}{c}01 \\
(4.4 \\
)\end{array}$ & $\begin{array}{c}01 \\
(5.0)\end{array}$ & $\begin{array}{c}01 \\
(11 . \\
1)\end{array}$ & Nil & $\begin{array}{c}03 \\
(25 . \\
0)\end{array}$ & $\begin{array}{c}01 \\
(5.5 \\
)\end{array}$ & $\begin{array}{c}03 \\
(12 . \\
5)\end{array}$ & Nil & Nil & Nil & $\begin{array}{c}01 \\
(16 . \\
7)\end{array}$ & Nil & $\begin{array}{c}12 \\
(8.8 \\
)\end{array}$ \\
\hline & otal & $\begin{array}{c}30- \\
89\end{array}$ & 164 & 108 & 23 & 20 & 09 & 02 & 12 & 18 & 24 & 04 & 08 & 06 & 88 & 58 & 272 \\
\hline
\end{tabular}

M-Male F-Female

rounded or both found in the same tissues and devoid of cytoplasm, in which the nuclear-cytoplasmic (N/C) ratio is 1:1 and so are non-keratinized. These NMSCs are poorly differentiated and observed in both carcinoma in situ and in frank malignant cases. Besides these, all other cells are highly keratinized, moderately differentiated and observed to be present at all stages of oral carcinogenesis (Figs.3-9).

Expression of keratin in the aforesaid pleomorphic cells in non-keratinized squamous epithelia of the oral cavity is a remarkable feature during carcinogenesis. The atypical pleomorphic cells are observed to be thicker, denser and hyperkeratinized in patients habituated with any form of tobacco and alcohol than the nonaddicted cancerous patients. Similarly, the exfoliated mucosal cells collected from occasionally habituated normal individuals are observed to be keratinized so far as non-habituated normal individuals are concerned in our study. The degree of keratinization is also observed to be varying from cell to cell in different sites of the same individual is probably due to the habit of keeping tobacco (khaini, gutkha, snuffs etc.), chewing of paan (betel) and paan masala at specific site of the oral cavity. Not only that smoking of tobacco (in the form of bidi and cigarette) and drinking of alcohol may induce the process of keratinization in different sites of the oral cavity demands further study. 
Table 2 Cellular differentiations of the control and cancer affected individuals with respect to sites and sex

\begin{tabular}{|c|c|c|c|c|c|c|c|c|c|c|c|c|c|c|}
\hline \multirow{3}{*}{ No } & \multirow{3}{*}{$\begin{array}{l}\text { Oral } \\
\text { Site }\end{array}$} & \multicolumn{6}{|c|}{ Control Group } & \multicolumn{6}{|c|}{ Cancer affected Group } & \multirow{3}{*}{ Total } \\
\hline & & \multicolumn{2}{|c|}{ WDSC } & \multicolumn{2}{|c|}{ MDSC } & \multicolumn{2}{|c|}{ PDSC } & \multicolumn{2}{|c|}{ WDSC } & \multicolumn{2}{|c|}{ MDSC } & \multicolumn{2}{|c|}{ PDSC } & \\
\hline & & M & $\mathrm{F}$ & M & $\mathrm{F}$ & M & $\mathrm{F}$ & M & $\mathrm{F}$ & M & $\mathrm{F}$ & M & $\mathrm{F}$ & \\
\hline 1 & Lip & $\begin{array}{c}05 \\
(6.1)\end{array}$ & $\begin{array}{c}06 \\
(11.1)\end{array}$ & Nil & Nil & Nil & Nil & $\begin{array}{c}02 \\
(4.8)\end{array}$ & $\begin{array}{c}04 \\
(13.4)\end{array}$ & $\begin{array}{c}02 \\
(8.0)\end{array}$ & $\begin{array}{c}01 \\
(8.3)\end{array}$ & $\begin{array}{c}01 \\
(6.7)\end{array}$ & $\begin{array}{c}01 \\
(8.4)\end{array}$ & 22 \\
\hline 2 & Tongue & $\begin{array}{c}11 \\
(13.4) \\
\end{array}$ & $\begin{array}{c}07 \\
(12.9)\end{array}$ & Nil & Nil & Nil & Nil & $\begin{array}{c}06 \\
(14.3)\end{array}$ & $\begin{array}{c}05 \\
(16.6)\end{array}$ & $\begin{array}{c}03 \\
(12.8)\end{array}$ & $\begin{array}{c}02 \\
(16.7)\end{array}$ & $\begin{array}{c}02 \\
(13.3)\end{array}$ & Nil & 36 \\
\hline 3 & $\begin{array}{c}\text { Alveolus and } \\
\text { gingiva }\end{array}$ & $\begin{array}{c}16 \\
(12.5)\end{array}$ & $\begin{array}{c}06 \\
(11.1)\end{array}$ & Nil & Nil & Nil & Nil & $\begin{array}{c}08 \\
(19.0)\end{array}$ & $\begin{array}{c}04 \\
(13.4)\end{array}$ & $\begin{array}{c}05 \\
(20.0)\end{array}$ & $\begin{array}{c}01 \\
(8.3)\end{array}$ & $\begin{array}{c}03 \\
20.0\end{array}$ & $\begin{array}{c}01 \\
(8.4)\end{array}$ & 44 \\
\hline 4 & $\begin{array}{l}\text { Floor of the } \\
\text { mouth }\end{array}$ & $\begin{array}{c}07 \\
(8.5)\end{array}$ & $\begin{array}{c}06 \\
(11.1)\end{array}$ & Nil & Nil & Nil & Nil & $\begin{array}{c}03 \\
(7.1)\end{array}$ & $\begin{array}{c}01 \\
(3.3)\end{array}$ & $\begin{array}{c}02 \\
(8.0)\end{array}$ & $\begin{array}{c}02 \\
(16.7)\end{array}$ & $\begin{array}{c}02 \\
(13.3)\end{array}$ & $\begin{array}{c}03 \\
(25.0)\end{array}$ & 26 \\
\hline 5 & Palate & $\begin{array}{c}06 \\
(7.3)\end{array}$ & $\begin{array}{c}03 \\
(5.6)\end{array}$ & Nil & Nil & Nil & Nil & $\begin{array}{c}03 \\
(7.1)\end{array}$ & $\begin{array}{c}01 \\
(3.3)\end{array}$ & $\begin{array}{c}02 \\
(8.0) \\
\end{array}$ & $\begin{array}{c}02 \\
(16.7)\end{array}$ & $\begin{array}{c}01 \\
(6.7)\end{array}$ & Nil & 18 \\
\hline 6 & Buccal mucosa & $\begin{array}{c}37 \\
(45.2)\end{array}$ & $\begin{array}{c}26 \\
(48.2)\end{array}$ & Nil & Nil & Nil & Nil & $\begin{array}{c}20 \\
(47.7)\end{array}$ & $\begin{array}{c}15 \\
(50.0)\end{array}$ & $\begin{array}{c}11 \\
(44.0)\end{array}$ & $\begin{array}{c}04 \\
(33.3)\end{array}$ & $\begin{array}{c}06 \\
(40.0)\end{array}$ & $\begin{array}{c}07 \\
(58.2)\end{array}$ & 126 \\
\hline 7 & Total & $\begin{array}{c}82 \\
(100)\end{array}$ & $\begin{array}{c}54 \\
(100)\end{array}$ & Nil & Nil & Nil & Nil & $\begin{array}{c}42 \\
(100)\end{array}$ & $\begin{array}{c}30 \\
(100)\end{array}$ & $\begin{array}{c}25 \\
(100)\end{array}$ & $\begin{array}{c}12 \\
(100)\end{array}$ & $\begin{array}{c}15 \\
(100)\end{array}$ & $\begin{array}{c}12 \\
(100)\end{array}$ & 272 \\
\hline
\end{tabular}

\section{M- Male F-Female}

\section{Discussion}

The process by which the structural protein is made tough and insoluble is known as keratinization, a process that results in a wide range of products and whose nature is far from being fully understood. In the oral cavity the lining mucous membrane becomes keratinized to varying degrees in different areas of the mouth. It has been observed that the oral epithelium of the human, has a surface which varies in its degree of keratinization from none at all, as in the cheek, through partial or parakeratinization, as found sometimes on the gingiva and parts of the palate, to full or orthokeratinization, as seen in most parts of the hard palate and overlying the gingival where it is attached to bone. The degree of keratinization-that is, the thickness of the keratin layer and whether para- or orthokeratinization occur is affected not only by genetic but also by the systemic factors. Nanci has reported that oral epithelium is classified into three types based on their morphology and specific pattern of differentiation: keratinized stratified squamous epithelium (masticatory mucosa distributed in hard palate and gingiva), non-keratinized stratified squamous epithelium (buccal mucosa, labial mucosa) and specialized mucosa (dorsal surface of the tongue) [13].

Keratinization, also termed as cornification, is a process of cytodifferentiation which the keratinocytes undergo when proceeding from their post germinative state (stratum basale) to finally differentiated, hardened cell filled with protein, constituting a structurally and functionally distinct keratin containing surface layer such as stratum corneum [9]. SCC is characterized by squamous differentiation (often seen as keratinization, sometimes with keratin pearl formation) and invasive growth with disruption of the basement membrane.

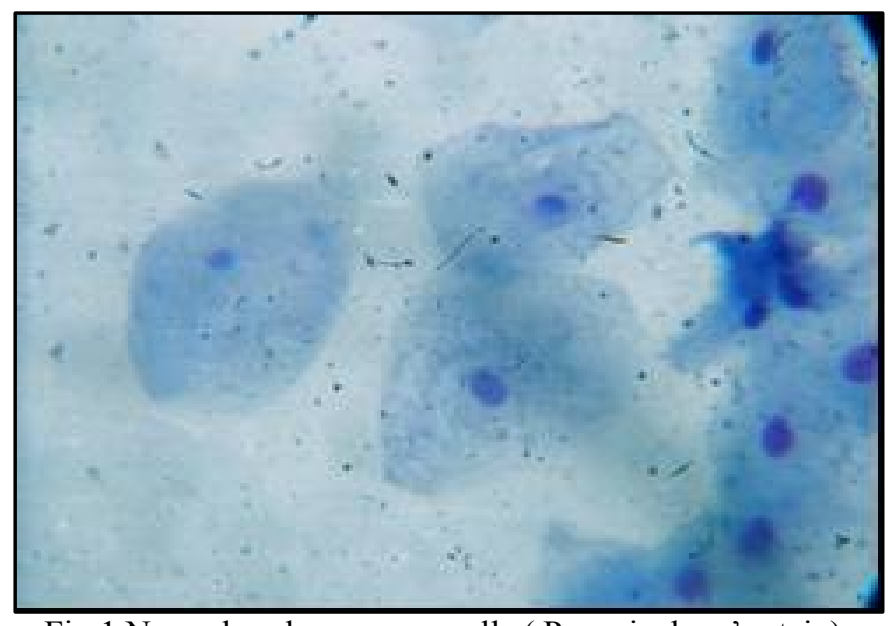

Fig.1 Normal oral squamous cells ( Papanicolaou's stain). 


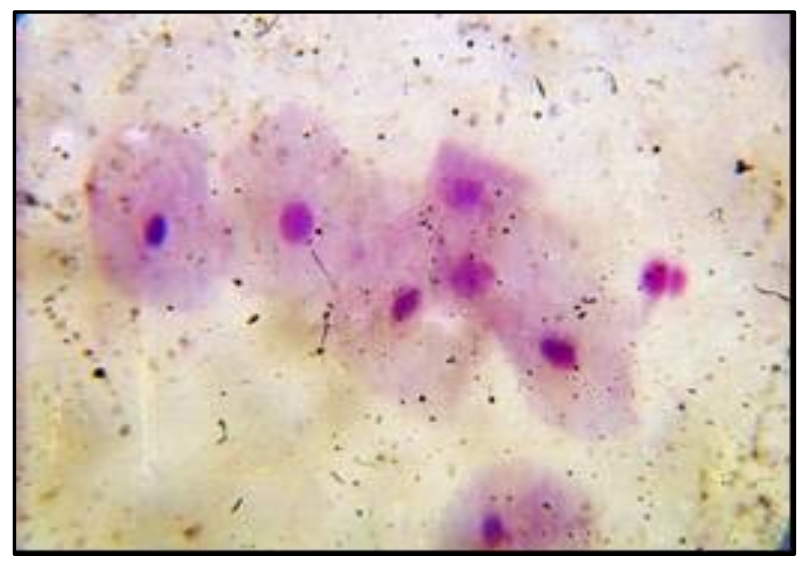

Fig.2 Normal oral squamous cells( Giemsa stain).

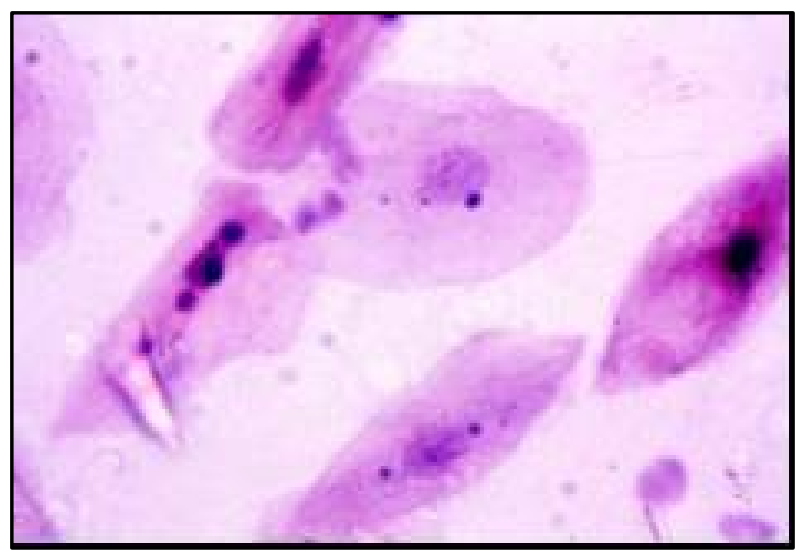

Fig.3 Micronucleated cells during leukoplakia.

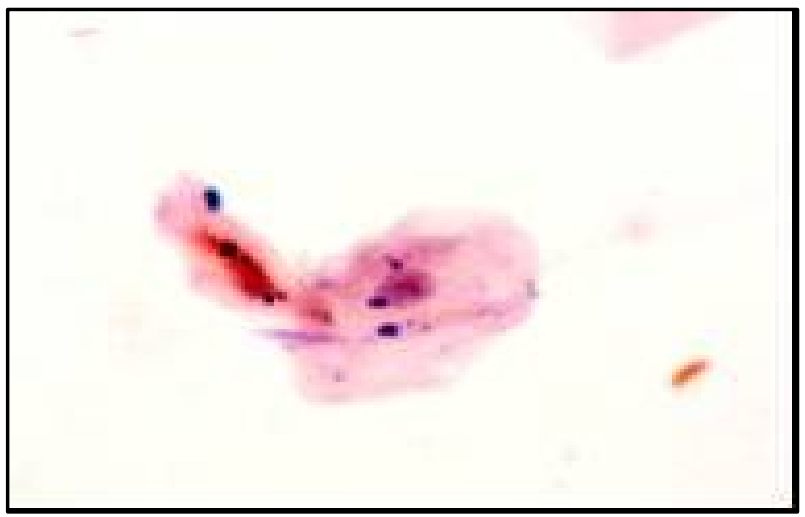

Fig.4 Micronucleated cells during erythroplakia .

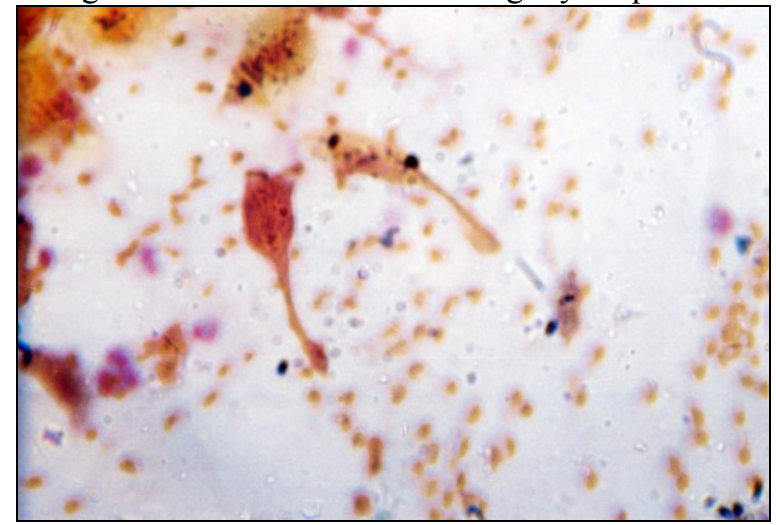

Fig.5 Keratinized tadpole cells (KTCs). 


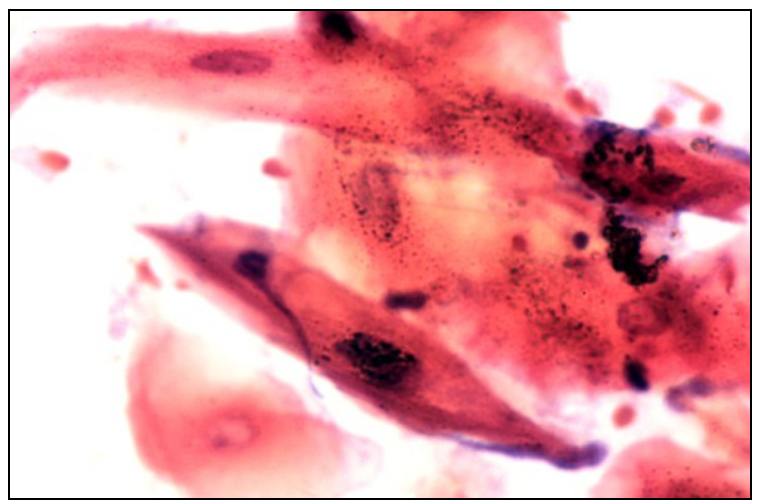

Fig.6 Keratinized spindle cells (KSCs).

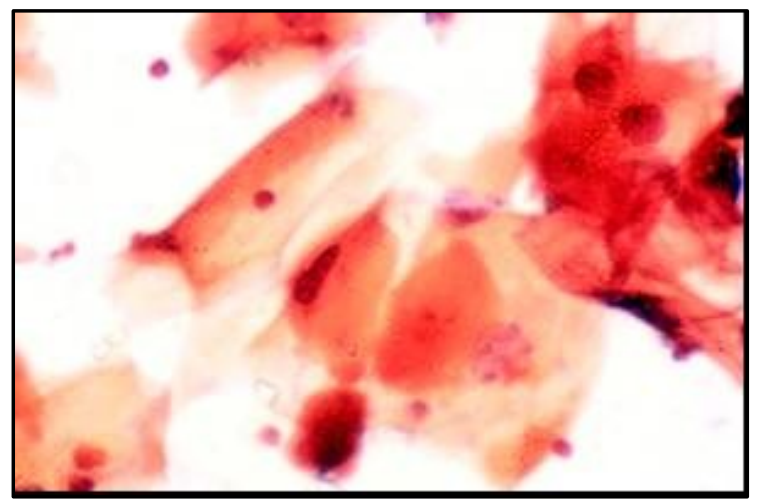

Fig.7 Well differentiated oral squamous cells (Hypo- and hyperkeratosis in PKSCs).

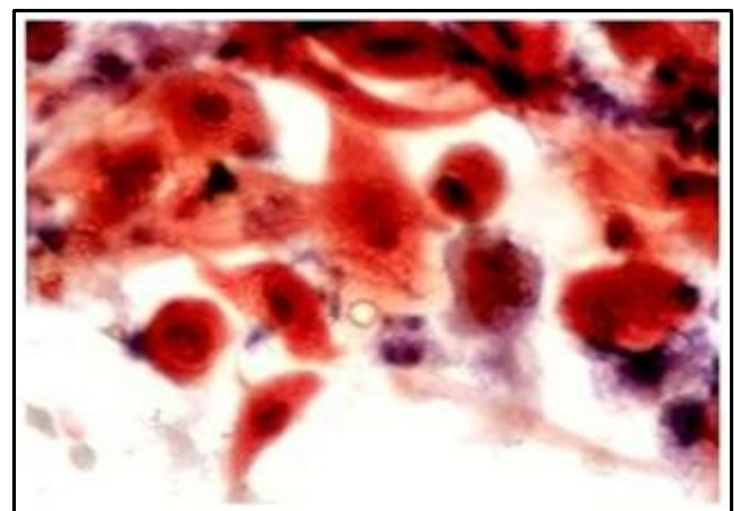

Fig.8 Moderately differentiated oral squamous cells (Hyperkeratinized pleomorphic squamous cells,viz. KSC, LKFC, SKRCs )

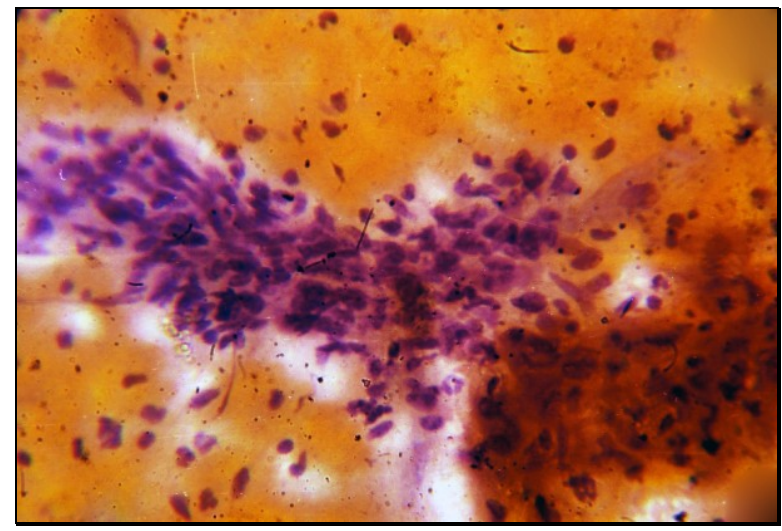

Fig.9 Poorly differentiated NMSCs at carcinoma in situ. 
SCC is graded into well-, moderately-, and poorly-differentiated. Well-differentiated SCC closely resembles normal squamous mucosa whereas moderately-differentiated SCC displays nuclear pleomorphism, mitoses (including atypical forms), and usually less keratinization. In poorly-differentiated SCC, immature cells predominate, with numerous typical and atypical mitoses, minimal keratinization, and sometimes necrosis. Most SCCs are moderately-differentiated [14-16]. Contrary to these reported facts, in our study, not only in welldifferentiated (PKSCs) but also in moderately differentiated squamous cells (viz. KSC, LKFC, SKRCs), both hypo- and hyper-keratinized pleomorphic cells are observed. These cells are mostly observed during premalignant stage and rarely during malignant stage of oral carcinogenesis. However, the poorly differentiated NKSCs are observed to be non-keratinized and are restricted to carcinoma in situ and malignant stages only.

During keratinization the water content of the cells decreases dramatically in spite of the fluid environment in the mouth. Keratin in the mouth remains relatively translucent as compared with skin, probably because it is kept moist and because the cornified layers are normally compact. In the mouth if the layers of keratin become broken up or if abnormal keratinization occurs there is a loss of translucency and the area appears white, perhaps because of the spaces in the cornified layer.

Keratin expression patterns are characteristic for distinct stages during cellular epithelial differentiation from embryonal to adult and of the internal maturation program during development [17]. Epithelial tumors including metastasis most widely retain their keratin patterns of their normal origin; thus the determination of the keratin patterns of tumors is widely exploited for cell and tumor typing. Therefore, keratins have evolved to be one of the most potent epithelial differentiation and tumor markers in cell biology, embryology, and surgical pathology [18]. Specific antibodies against several keratins are routinely used for immunohistochemical typing of carcinoma in tumor diagnostics. Keratins can be used as differentiation markers in normal oral epithelia [10].

Endoscopically, the lesions may be discrete or diffuse, smooth or irregular, flat or exophytic. Precursor lesions may present as a small flat patch or as a large warty plaque. The surface may be brown to red (erythroplakia) or present with circumscribed whitish plaques (leukoplakia). White patches may be ulcerated. Leukoplakia, in contrast to erythroplakia, tends to be well demarcated and seems to have a lower risk of malignant transformation. The lesions are commonly diffuse, with a thickened appearance. Malignant transformation of the mucosal lining is a genetic process resulting from accumulation of multiple genetic alterations that dictates the frequency and pace of progression to invasive carcinoma. It is generally accepted that most sporadic tumors are the result of a multi-step process of accumulated genetic alterations. These alterations affect epithelial cell behaviour by way of loss of chromosomal heterozygosity ( $\mathrm{LoH})$ which in turn leads to a series of events progressing to the ultimate stage of invasive squamous cell carcinoma. The corresponding genetic alterations are reflected in clinical and microscopic pathology from hyperplasia through invasiveness [19]. LoH studies indicate that the earliest alterations appear to target specific genes located on chromosomes 3p14, 9p21 (CDKN2A), and 17p13 (TP53). Alterations that tend to occur in association with higher grades of dysplasia and SCC include cyclin D1 amplification, PTEN inactivation, and LOH at 13q21, 14q32, 6p, 8, 4q27, and 10q23 [14]. ${ }^{3}$ Keratinization of tumors and the high expression of microRNAs (miRNAs) were the major factors related to the poor prognosis of patients. Interestingly, a majority of the keratinized tumors expressed high levels of miR-21 [20]. The potential to identify accurately and prospectively the subset of dysplastic lesions which are likely to progress through dysplasia to cancer are of premier scientific and clinical significance. Thorough examination and appropriate selection of biopsy sites, coupled with expert histopathologic evaluation, are required for diagnosis of oral leukoplakia and erythroplakia [21]. Analysis of correlations between biomarkers, stages of dysplasia and their progression to OSCC is complex and it requires incorporation of multiple variables [22]

In our study, it has been revealed that the keratinizing SCC, unlike the non-keratinizing counterpart presents with pleomorphic, highly keratinized squamous cells. These cells vary greatly in size and shape and tend to occur singly with few small groups or syncytial arrangements. Squamous cells with bizarre shapes, such as spindle, strap, fibre, round, caudate tadpole, etc., present a characteristic picture on the routine Papanicoloau's stain test. The changes can be confidently identified as true pleomorphism and not due to smearing artifact. The exaggerated cell to cell variability both in cell size and more importantly, cell shape, distinguishes keratinizing SCC from keratinizing dysplastic lesions. Similar variability in the size and shape of the nuclei are also seen. Nuclei exhibit pycnotic and prominent hyperchromasia, so called "ink-dot black", and at times can appear "ghost like" because of the abundant keratinization. Another feature observed due to the abundant keratinization is keratinized blebs of cytoplasm extending from the body of the cell. This feature leads to the pleomorphic appearance.

Keratins play a major functional role in the integrity and mechanical stability of both the single epithelial cells and via cell to cell contacts of that of the epithelial tissues [23]. In humans, keratins are encoded in 54 genes and these genes are clustered on two chromosomes. The acidic type I keratin genes are clustered on chromosome 17 and the basic type II keratin genes are clustered on chromosome 12 [24-26].The expression of specific keratin genes is regulated by the differentiation of epithelial cells within the stratifying squamous 
epithelium [27]. Mutations in most of these genes are now associated with specific tissue fragility disorders which may manifest both in skin and mucosa depending on the expression pattern [10]

The production of specific types of cytokeratins by different cell types as well as in individual cells of the oral epithelium reflects the degree of cellular differentiation and maturation [28, 29]. Keratins and certain keratin associated proteins are useful as markers of differentiation because their expression is both region and differentiation specific [30,31]. Certain basic keratins are minor constituents of the cytoskeleton that are expressed in the suprabasal cells of various stratified soft-keratinizing epithelia [32]. K76 is produced in the upper layers of the stratified epithelium of the hard palate and gingiva [33]. K78 is produced in the cells of the epithelial covering of the human tongue while $\mathrm{K} 80$ is produced in the suprabasal cells of the epithelium of the human tongue [34]. Kanojia et al. have reported that there was an increased level of K5/ K6a and aberrant expression of K8 in dysplastic papillomatous lesions and carcinoma tissues of lingual epithelium. K6 is a marker of cell proliferation and its over expression has been observed in hyperproliferative disorder [35]. K26 is exclusively specific to taste bud anlagen in developing oral mucosa [36]. K24 is sometimes expressed in the epithelium of tongue. Myoepithelial cells were found to express K17 [37].

There are around 30 families of keratin proteins divided into two groups namely acidic and basic which are arranged in pairs and different studies have suggested that this coexpression seems to be more pronounced in poorly differentiated squamous cell carcinomas. Stratified-epithelial keratins, in particular K5 and K6, are useful as general markers for squamous cell carcinomas in histologically uncertain, poorly differentiated, or metastatic tumor cases $[38,39]$. K8/18 serve as markers for simple epithelial differentiation, $\mathrm{K} 1 / 10$ are markers for keratinized epithelium, and $\mathrm{K} 4 / 13$ can be used as markers for non-keratinized epithelium. K6/16 is considered as hyperproliferative marker which are expressed in sites of high epidermal keratinocyte turnover and in pathological hyperproliferative conditions affecting the skin [40]. In the oral cavity, there is increased expression of K1/10, K4/13 in well-differentiated oral squamous cell carcinomas. Less well-differentiated oral squamous cell carcinoma express neither of these keratin pairs to any significant extent but cells in the basal cell layer of oral epithelium do express K19 and K14 and reflects its proliferation potential, while cells in the suprabasal instead produce K1 and K10. When K19 is produced by suprabasal cells of the oral mucosa, this indicates alteration in cell behaviour and probable premalignant changes [41]. Moderated and poorly differentiated oral squamous cell carcinoma may express K8 and sometimes K7 and 18. Also K5 and K6 are considered as useful markers for squamous cell carcinomas in histologically uncertain, poorly differentiated or metastatic tumor cases $[33,38]$. It has been reported that $\mathrm{K} 8$ is associated with transformation and increased malignant potential of oral squamous epithelial cells [34]. Recently, it has also been demonstrated that the expression of $\mathrm{K} 8$ and $\mathrm{K} 18$ is an independent prognostic marker in squamous cell carcinomas of the oral cavity and indicates a decreased overall and progression-free survival [42].

\section{Conclusion}

Different studies suggest that conversion rate of precancer to cancer varies significantly and alteration predominantly begin after the dysplastic changes during oral carcinogenesis. Malignant transformation of the mucosal lining is a genetic process resulting from accumulation of multiple genetic alterations that dictates the frequency and pace of progression to invasive carcinoma. Site specific expression of keratins in oral mucosa is nothing but the ultimate result of genetic alteration in the respective site. Accumulation and pattern of keratin expression in oral squamous cells are essentially of the same kind in both normal and malignant cells. At the onset of keratinization, the cytoplasm usually increases in volume, relatively to the nucleus. Lobed and fragmented nuclei, as well as amitotic nuclear division, are probably indications of attempts at readjustment of the normal nuclear-cytoplasmic relationship which lead to cytological pleomorphism. Pattern of keratinization In the pleomorphic oral squamous cells has a practical utility in the diagnosis and early detection during oral carcinogenesis Although, the pattern of keratinization during oral carcinogenesis is less understood, the impact of various etiologic factors like tobacco and alcohol and their role in the process of keratinization needs further study.

\section{Acknowledgements}

Authors are thankful to the Head, P.G. Dept. of Zoology, Utkal University, Vani Vihar, Bhubaneshwar, Odisha for providing laboratory and library facilities; to the Director, Acharya Haihar Regional Cancer Center (AHRCC), Cuttack, Odisha for permitting us to collect samples from the oral cancer patients and also for providing library and laboratory facilities and one of us (AM) is grateful to the University Grants Commission (UGC), New Delhi for awarding UGC Meritorious Research Fellowship to carry out the research work.

\section{References}

[1] H.H. Bragulla, D.G. Homberger, Structure and functions of keratin proteins in simple, stratified, keratinized and cornified epithelia, J Anat, 214(4), 2009, 516-559.

[2] M. Er Rafik, J. Doucet, F. Briki, The intermediate filament architecture as determined by X-ray diffraction modeling of hard alpha keratin, Biophys J, 86(6), 2004, 3893-3904. 
[3] W.W.Franke, D.L.Schiller, R.Moll, S.Winter, E Schmid, I. Engelbrecht, D. Helmut, K. Reinhard, P. Beatrix, Diversity of cytokeratins. Differentiation specific expression of cytokeratin polypeptides in epithelial cells and tissues, J Mol Biol, 153(4), 1981, 933-959.

[4] R.B. Presland, B.A. Dale, Epithelial structural proteins of the skin and oral cavity: function in health and disease, Crit Rev Oral Biol Med, 11(4), 2000, 383-408.

[5] B.A. Dale, J .Salonen, A.H. Jones, New approaches and concepts in the study of differentiation of oral epithelia, Crit Rev Oral Biol Med,1(3), 1990, 167-190

[6] P.E.Bowden. The human type II keratin gene cluster on chromosome 12q13.13: final count or hidden secrets?, J Invest Dermatol ,24, 2005; xv-xvii.

[7] J. Schweizer, P.E. Bowden, P.A. Coulombe, L. Langbein, E.. Birgitte Lane, T.M.. Magin, L. Maltais, M. B. Omary, D.A.D.. Parry, M.A. Rogers, M.W. Wright, New consensus nomenclature for mammalian keratins, J Cell Biol, 174, 2006, $169-174$.

[8] P.A. Coulombe, X. Tong, S. Mazzalupo, Z. Wang, P. Wong. Great promises yet to be fulfilled: Defining keratin intermediate filament function in vivo, Euro J Cell Biol, 83(11-12), 2004, 735-746(12).

[9] R.G. Oshima, Intermediate filaments: a historical perspective, Exp Cell Res, 313(10) 2007, 1981-1994.

[10] S. Shibani, S. Gokul. Keratinization and its Disorders, Oman Medical Journal, 27(5), 2012, 348-357.

[11] A. Mohanta, P.K. Mohanty, G. Parida, Diagnostic cytological pleomorphism in oral squamous cell carcinoma (OSCC), Proceedings of the International Symposium on Emerging Trends in Biomedicine and Nano-biotechnology: Relevance to Human Health. Acharya Nagarjuna University, Guntur, Andhra Pradesh, India, 2009, 237-238.

[12] R.G.W. Taylor, Practical Cytology (Academic Press, London and New York, 1967).

[13] A .Nanci. Ten Cate's Oral Histology. 6th edtn (Elsevier; 2003).

[14] L. Barnes, J.W. Eveson, P. Reichart, D.Sidransky, Pathology and Genetics of Head and Neck Tumours (World Health Organization Classification of Tumours, IARC Press, Lyon , 2005).

[15] L.D.R.Thompson, Head and Neck Pathology. Foundations in Diagnostic Pathology Series, (Churchill Livingstone, Elsevier, Philadelphia, 2006)

[16] S. Warnakulasuriya, J. Reibel, J. Bouquot, E. Dabelsteen, Oral epithelial dysplasia classification systems: predictive value, utility, weaknesses and scope for improvement, J Oral Pathol Med, 37, 2008, 127-33.

[17] M. Osborn, K. Weber, Tumor diagnosis by intermediate filament typing: A novel tool for surgical pathology, Lab Invest, 48, 1983, 372-394.

[18] R.B. Nagle, Intermediate filaments. Efficacy in surgical pathologic diagnosis, Am J Clin Pathol, 91 (Suppl 1), 1989, S14-S18.

[19] J.J. Sciubba, Oral cancer. The importance of early diagnosis and treatmen,. Am J Clin Dermatol, 2(4), 2001, 239-51.

[20] H.M. Jung, B.L. Phillips, R.S. Patel, D.M. Cohen, A. Jakymiw, W.W. Kong, J.Q. Cheng, E.K.L.Chan, Keratinization-associated miR-7 and miR-21 Regulate Tumor Suppressor Reversion-inducing Cysteine-rich Protein with Kazal Motifs (RECK) in Oral Cancer, J Biol Chem, 287, 2012, 29261-29272.

[21] J.B .Epstein, L .Zhang, M. Rosin, Advances in the Diagnosis of Oral Premalignant and Malignant Lesions. J Can Dent Assoc, 68(10), 2002, 617-21.

[22] C. Seethalakshmi. Early Detection of Oral Squamous Cell Carcinoma (OSCC) - Role of Genetics: A Literature Review, Journal of Clinical and Diagnostic Research, 7(8), 2013, 1824-1826.

[23] R. Moll, M. Divo, L. Langbein. The human keratins: biology and pathology, Histochem Cell Biol, 129(6), 2008, 705-733.

[24] P.E. Bowden, R.A. Quinlan, D. Breitkreutz, N.E. Fusenig, Proteolytic modification of acidic and basic keratins during terminal differentiation of mouse and human epidermis, Eur J Biochem, 142, 1984, 29-36.

[25] M. Hesse, T.M. Magin, K. Weber, Genes for intermediate filament proteins and the draft sequence of the human genome: novel keratin genes and a surprisingly high number of pseudogenes related to keratin genes 8 and 18, J Cell Sci,114, 2001,2569-2575.

[26] P.A .Coulombe, M.B. Omary, 'Hard' and 'soft' principles defining the structure, function and regulation of keratin intermediate filaments, Curr Opin Cell Biol, 14(1), 2002, 110-122.

[27] J. Uitto, G. Richard, J.A. McGrath, Diseases of epidermal keratins and their linker proteins. Exp Cell Res. 313(10), 2007,1995-2009.

[28] K. Lindberg, J.G. Rheinwald, Suprabasal 40kd keratin (K19) expression as an immunohistologic marker of premalignancy in oral epithelium, Am J Pathol, 134(1), 1989, 89-98.

[29] V. Barak, H .Goike, K.W. Panaretakis, R. Einarsson, Clinical utility of cytokeratins as tumor markers, Clin Biochem, 37(7), 2004, 529-540.

[30] M. Hesse, A. Zimek, K.Weber, T.M. Magin,Comprehensive analysis of keratin gene clusters in humans and rodents. Eur J Cell Biol, 83, 2004, 19-26.

[31] M.M. Vaidya, D. Kanojia, Keratins: markers of cell differentiation or regulators of cell differentiation?, J Biosci, 32(4), 2007, 629634.

[32] A. Heyden, H.S. Huitfeldt, H.S. Koppang, P.S. Thrane, M. Bryne, P. Brandtzaeg, Cytokeratins as epithelial differentiation markers in premalignant and maligmnant oral lesions, J Oral Pathol.Med , 21, 1992, 7-11.

[33] M.A. Rogers, H. Winter, L. Langbein, .R Bleiler, J .Schweizer, The human type I keratin gene family: characterization of new hair follicle specific members and evaluation of the chromosome 17q21.2 gene domain, Differentiation, 72(9-10), 2004, 527-540.

[34] M.A. Rogers, L. Edler, H. Winter, L. Langbein, I. Beckmann, J .Schweizer, Characterization of new members of the human type II keratin gene family and a general evaluation of the keratin gene domain on chromosome 12q13.13, J Invest Dermatol, 124(3), 2005, 536-544.

[35] D. Kanojia, S.S. Sawant, A.M. Borges, A.D. Ingle, M.M. Vaidya, Alteration in keratins and associated proteins during 4Nitroquinoline-1-oxide induced rat oral carcinogenesis, J Carcinogen, 11, 2012, 1-8.

[36] M. Witt, M. Kasper, Distribution of cytokeratin filaments and vimentin in developing human taste buds, Anat Embryol (Berl) 199(4), 1999, 291-299.

[37] I.M. Freedberg, M. Tomic-Canic, M. Komine, M. Blumenberg, Keratins and the keratinocyte activation cycle, J Invest Dermatol 116(5), 2001, 633-640.

[38] R. Moll, Cytokeratins as markers of differentiation in the diagnosis of epithelial tumors, Subcell Biochem, 31, 1998, 205-262.

[39] D. Dabbs, Diagnostic Immunohistochemistry (Churchill Livingstone Elsevier, Philadelphia, 2006).

[40] P.R. Morgan, P.J. Shirlaw, N.W. Johnson, I.M. Leigh, E.B. Lane, Potential applications of anti-keratin antibodies in oral diagnosis , J Oral Pathol , 16(4),1987, 212-222.

[41] L.P. Zhong, W.T. Chen, C.P. Zhang, Z.V. Zhang, Increased CK19 expression correlated with pathologic differentiation grade and prognosis in oral squamous cell carcinoma patients, Oral Surg Oral Med Oral Pathol Oral Radiol Endod, 104(3), 2007, 377-84.

[42] T. Fillies, R.Werkmeister, J. Packeisen, B. Brandt, P. Morin, D. Weingart, U. Joos, H. Buerger, Cytokeratin 8/18 expression indicates a poor prognosis in squamous cell carcinomas of the oral cavity, BMC Cancer, 6, 2006, 10. 